\title{
SEOM clinical guideline for secondary prevention (2019)
}

\author{
A. Santaballa ${ }^{1}$ - Á. Pinto ${ }^{2} \cdot$ R. P. Balanyà ${ }^{3} \cdot$ N. Ramírez Merino ${ }^{4} \cdot$ I. R. Martín ${ }^{5} \cdot$ S. S. Grau ${ }^{6} \cdot$ J. P. B. Fombella ${ }^{7}$. \\ J. M. Cano ${ }^{8} \cdot$ C. H. González ${ }^{9} \cdot$ J. Bayo $^{10}$
}

Received: 10 January 2020 / Accepted: 10 January 2020 / Published online: 31 January 2020

(c) The Author(s) 2020

\begin{abstract}
Cancer is one of the major public health problems in our society. It is estimated that more than 18 million new cases are diagnosed worldwide every year; 280,000 in Spain. Incidence in following a growing trend. This epidemic could be controlled with research into new treatments and, above all, with adequate prevention. Primary prevention could prevent avoid up to half of all cases. For many others, secondary prevention is essential, as it make diagnosis possible in the stages of the disease when it is easily curable. These guidelines present the scientific evidence regarding secondary prevention in tumors in which its use is well-accepted: breast, cervical, colorectal, prostate, lung, ovarian, melanoma, and gastric cancer.
\end{abstract}

Keywords Secondary prevention $\cdot$ SEOM $\cdot$ Cancer $\cdot$ Early diagnosis

\section{Introduction}

Cancer is a public health problem. Its incidence around the world has increased, reaching 18.1 million new cases in the year 2018, with a mortality rate of 9.6 million cases/ year [1]. In Spain, the estimated incidence of cancer for the year 2019 is 277,000 new cases/year [2].
The World Health Organization (WHO) defines prevention as "the measures aimed, not only to prevent the occurrence of disease, such as risk factor reduction, but also to arrest its progress and reduce its consequences once established" [3]. Thus, prevention requires anticipatory actions, as well as a keen understanding of the natural course of the disease. There are different levels of intervention in

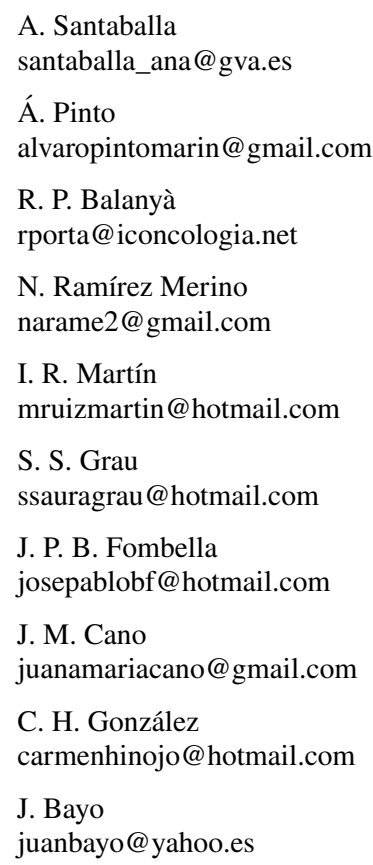

1 Medical Oncology Department, Hospital Universitari I Politècnic la Fe, Valencia, Avda. de Fernando Abril Martorell, 106, 46026 Valencia, Spain

2 Medical Oncology Department, Hospital Universitario la Paz, Madrid, Spain

3 Medical Oncology Department, Hospital Universitari Dr. Josep Trueta, ICO Girona, Girona, Spain

4 Medical Oncology Department, Centro Integral Oncológico Clara Campal (CIOCC), Madrid, Spain

5 Medical Oncology Department, Hospital Rio Carrión, Palencia, Spain

6 Medical Oncology Department, Hospital Universitario de Gran Canaria Dr. Negrín, Las Palmas, Spain

7 Medical Oncology Department, Hospital Universitario Central de Asturias, Oviedo, Spain

8 Medical Oncology Department, Hospital General de Ciudad Real, Ciudad Real, Spain

9 Medical Oncology Department, Hospital Universitario Marqués de Valdecilla, IDIVAL, Santander, Spain

10 Medical Oncology Department, Hospital Juan Ramón Jiménez, Huelva, Spain 
preventions, depending on the stage of the natural history of the disease in which we execute the actions. We, therefore, distinguish between: primary, secondary, and tertiary prevention [4]. This guide will focus of reviewing secondary prevention.

Secondary prevention (early detection, screening) is aimed at detecting the illness in its incipient stage, in apparently healthy individuals, with the aim of enabling treatment to be administered during the early stage, having a better chance at being efficacious, improving prognosis, and, ultimately, lowering mortality due to the disease. For these activities to be truly efficacious and have the desired impact on health, they must be carried out solely for those diseases and in those population groups in which they have proven beneficial effects (decreased mortality and, when applicable, incidence, improved quality of life, etc.), offsetting the pitfalls that always derive from the activity (false-positive and negative results, overdiagnosis, overtreatment, adverse effects from the testing, etc.). The structure of organized programs encompassing all activities must be planned, coordinated, monitored, and evaluated, within the framework of continuous quality improvement, guaranteeing the principles of efficiency and equality.

The conditions that make certain cancers susceptible to early diagnosis have to do with the disease (magnitude, transcendence, and natural history), with the screening test (validity, acceptability, cost, etc.), the diagnostic-treatment process (validated protocols and guidelines), as well as the program itself (proof of impact, resources, etc.).

Raising people's awareness of the importance of knowing and detecting the early signs or symptoms of a disease, as well as making healthcare professionals cognizant of the importance of referring individuals to confirm diagnosis and, if pertinent, to initiate treatment as promptly as possible, round out the activities targeting early detection and must be taken into account for the integral approach to the illness in question.

\section{Breast cancer}

The scientific evidence currently available prove that mammograms reduce mortality due to breast cancer by at least $20 \%$ and, consequently, continues to be the mainstay of early detection of breast cancer [5, 6]. Nevertheless, the magnitude of the benefit is not the same across all age groups. The group of low-moderate risk women ages 50-69 years is the one that obtains the greatest net benefit from mammograms (Grade 1B) performed every 2 years (Grade 2C). Mammograms can be recommended for women with ages between 45-49 and 70-74 years, although there are impediments to being able to establish a conclusion regarding the net benefit in these cases (Grade
2C). Screening is not routinely recommended for women under the age of 45 or over the age of 74 years.

Magnetic resonance is more sensitive, albeit less specific tan mammograms and appears to be particularly efficacious as a complement to mammograms in women at high risk for breast cancer (mutations of the BRCA or other susceptibility genes; prior chest radiotherapy; family or personal history of breast and ovarian cancer) (Grade $2 \mathrm{~A})$. Nonetheless, the benefit of detections by magnetic resonance on survival in high risk groups has not been demonstrated [7].

The beneficial effect of breast self-examination or effectiveness of clinical examination has not been proven. Moreover, breast self-examination is associated with higher biopsy rates for benign disease [8]. Therefore, neither clinical examination (Grade 2C) or breast self-examination (Grade 2B) are recommended. However, educating women about recognizing breast cancer is suggested so that they will be capable of recognizing changes for which they should seek care.

\section{Cervical cancer}

The human papillomavirus (HPV) is the leading cause of cervical cancer (CC) and its precursor lesions. The HPV is sexually transmitted in males and females, as well as by skin and mucous membranes, and is also associated with cancer of the anus, vulva, vagina, penis, and pharynx. That is why healthcare professionals should advise about protection during sexual contact.

We presently have enough evidence that $\mathrm{CC}$ screening is correlated with decreased incidence and lower mortality due to CC [9]. CC screening can be conducted by cervical cytology or via HPV detection.

The implementation of screening with cytology has accounted for between 60 and $90 \%$ decrease in the incidence of CC, although its weakness is its limited sensitivity (approx. 50\%). HPV detection techniques are more sensitive for the detection of precancerous lesions and have a better negative predictive value, although if used without control, they can lead to a significant increase in the rate of false-positive results and of over diagnosis of lesions that would not progress. Their use is recommended as a primary test and cytology only performed if the result is positive [10].

The latest update of the national healthcare's portfolio of service includes populational screening for cervical cancer as a basic service in the target population of women between 25 and 65 years of age. The screening tests, as well as the interval between examinations contemplated are specified in Table 1. 


\section{Colorectal cancer}

Colorectal cancer (CRC) is one of the tumors with the highest incidence and currently represents the second leading cause of cancer deaths in our country [11]. Numerous studies have revealed significant decreases in the incidence of and mortality from CRC among the population who have been screened for the disease, thanks to the detection of tumors in early stages and to the excision of premalignant polyps.

Individuals aged $\geq 50$, without any other added risk factors, are considered to comprise the intermediate risk population for CRC, and it is recommended that they be included in screening programs $[12,13]$ (Grade 1A). There are currently different strategies, without conclusive data as to the superiority of one over the others [14], although with varying sensitivity and specificity to detect polyps and CRC.

- Fecal occult blood test (FOBT) is a useful tool to screen for CRC (Grade 1A).

- The immunohistochemical test (FOBTi) exhibits greater sensitivity and compliance compared to the guaiac test (FOBTg), although the latter is also an alternative for early detection.

- Fecal DNA analysis can be considered a possible tool for early CRC detection, although its poorer specificity with respect to FOBTi and its elevated cost limit its applicability as the number one option.

- Flexible sigmoidoscopy every 5 years is an efficacious test to screen for CRC (Grade 1A). If hyperplastic polyps measuring more than $1 \mathrm{~cm}$ or adenomas or sessile serrated polyps of any size are detected, a complete colonoscopy should be performed.
- Complete colonoscopy is the most sensitive screening test and enables premalignant polyps to be removed. If there are no significant findings, complete colonoscopy is recommended every 10 years (Grade 1A).

- CT colonography every 5 years can also be contemplated as an alternative for early detection (Grade 2B), especially when other options are either not available or are discouraged.

\section{CRC screening recommendation in Spain}

Populational colorectal cancer screening is covered in all Autonomous Communities. The entire population should be included in organized, populational programs by the year 2024.

If the FOBT is positive, a complete colonoscopy should be carried out (Grade 1A).

Individuals included in high risk groups (family or personal history of polyps or CRC, Lynch syndrome, intestinal inflammatory disease, etc.) must be identified, given that they can benefit from specific screening strategies (Grade 1A).

\section{Prostate cancer}

Secondary prevention of prostate cancer is one of the most controversial aspects of all urological neoplasms. The available evidence from randomized clinical trials, such as the ERPSC or PLCO studies, demonstrated that screening for prostate cancer with PSA determinations, with or without digital rectal examination, in asymptomatic males, has a minimal impact on prostate cancer mortality and has no impact on overall all-cause survival [15]. Moreover, prostate cancer screening is associated with potential risks, such as false positives, biopsies, and other unnecessary diagnostic

Table 1 Recommendation of the Spanish Ministry of Health for cervical cancer screening (2019)

\begin{tabular}{|c|c|c|}
\hline $\begin{array}{l}\text { Target population (women } \\
\text { between } 25-65 \text { years of age) }\end{array}$ & Age $25-34$ years & Age $35-65$ years \\
\hline \multirow[t]{2}{*}{ Recommendation } & Cytology every 3 years & $\begin{array}{l}\text { High risk HPV determina- } \\
\text { tions (HPV-AR): } \\
\text { * If HPV-AR is negative, } \\
\text { repeat HPV-AR testing at } \\
5 \text { years } \\
\text { * If HPV-AR is positive, tri- } \\
\text { age with cytology } \\
\text { If the cytology is negative, } \\
\text { repeat HPV-AR } 1 \text { year later }\end{array}$ \\
\hline & Grade: $1 \mathrm{~A}$ & Grade: $1 \mathrm{~A}$ \\
\hline Conclude screening & \multicolumn{2}{|c|}{$\begin{array}{l}\text { Screening will conclude at } 65 \text { years of age, as long as there is existing adequate, negative screening (10 years) } \\
\text { and there is no history of CIN or CC ( } 20 \text { years) } \\
\text { Recommendation Grade: D }\end{array}$} \\
\hline
\end{tabular}

${ }^{a}$ These recommendations should be reviewed regularly, especially with respect to screening suitably vaccinated women [10]

${ }^{\mathrm{b}}$ Other international guidelines advise initiating screening at 21 years of age (for instance, the USPSTF-U.S. Preventive Services Task Force) 
procedures, and, above all, over diagnosis and complications derived from the treatment of tumors that would never have clinically manifested.

With these data, PSA-based populational screening is not deemed necessary. Individually, and in all cases depending on personal characteristics, men should be informed of the advantages and disadvantages of the screen process, and should participate in making pertinent decisions. Initiating the conversation about screening at 50 years of age with an individual who is not at excessive risk for prostate cancer might be contemplated [16]. In fact, some guidelines recommend proposing that the decision as to whether to undergo screening or not to men between 55 and 69 years of age, including the discussion regarding the possible risks and benefits [17].

Notwithstanding the above, the most widely accepted general recommendation is to refrain from screening in men who are not at high risk. Cases with a prior family history of prostate cancer, or with known alterations of the BRCA1/2 genes, might initiate this process at $40-45$ years of age. In men over the age of 70 or with a life expectancy of less than 10 years, screening is discouraged (Grade 1D). In contrast, the healthcare professional should not perform screening procedures in a individuals who have not been previously informed or who are not willing [to undergo screening] (Grade 1C).

If the decision to proceed with the screening is finally made, the most widely recommended strategy is PSA determinations every 1-2 years, without digital rectal examination.

\section{Lung cancer}

According to the data published by the IARC, deaths due to lung cancer (LC) represent $20 \%$ of all cancer deaths in Spain, making it the leading cause of death from cancer (globocan http://gco.iarc.fr/tomorrow/). The increase in mortality among with is particularly concerning. These data reflect an important public health problem and, despite the extraordinary primary preventive measures that are being undertaken, $25 \%$ of the Spanish people continue to smoke [18].

From the beginning of this century, randomized clinical trials have been conducted to ascertain the relevance of secondary prevention in lung cancer-related mortality. The study with the largest sample (53,454 participants), the National Lung Screening Trial NLST [19], carried out a head-to-head comparison of the efficacy of low density computerized tomography (LDCT) and simple chest X-ray in high-risk subjects defined as: smokers or former smokers, aged 55-74 years, who had smoked a minimum of 30 pack/ year for no fewer than 15 years. The study results revealed a $20 \%$ decrease of the relative risk (RR) of mortality due to LC (95\% CI 6.8-26.7; $p=0.004)$ and established LDCT as the technique of choice for early detection of LC.

In the European NELSON study, with 15,792 subjects, annual LDCT in high-risk subjects for 10 years lowered mortality by $26 \%$ in males and by up to $61 \%$ in females [20]. An important difference in the management of pulmonary nodules between the NELSON and NLST studies was the use of nodule volume and volume-doubling time to identify possible cases of early lung cancer.

Other studies with fewer subjects have studied the viability of LC screening, as well as other psychosocial and economic aspects [21].

With the results of the NLST study, the US Preventing Services Task Force establishes a GRADE 1B recommendation for screening for LC in high-risk patients, as long as smoking cessation and LDCT are advised [22].

The European Union also issued its recommendations in 2017 [23] in which it concludes that planning for the implementation of LDCT must begin all over Europe, pointing out the issues that must be resolved prior to its general application, such as, how to stratify risk for the selection of eligible populations, definitions of what comprises a positive result, interval between examination, duration of screening, diagnostic management of the lesions detected and of incidental findings, etc. All of these matters are key to being able to launch the startup of these programs.

\section{Secondary prevention of other tumors}

\section{Ovarian cancer}

There is no evidence that points to transvaginal ultrasound and CA 125 determination having proven their effectiveness as screening procedures in the general population [24]. The recommendations proposed by various bodies, such as the US Preventive Services Task Force [25], refer to insufficient evidence (Grade 2D) to recommend these two tests as screening procedures in the general population over the age of 40 years. In women at high risk for hereditary syndromes (for example, hereditary breast and ovarian cancer syndrome associated with BRCA1 and BRCA2 gene mutations), routine monitoring is recommended with determinations of the marker CA 125, gynecological and transvaginal US every 6-12 months, starting at 35 years of age, but with guaranteeing early diagnosis of ovarian cancer (Grade 2B). Bilateral salpingoophorectomy after fulfilling their child-bearing desires is recommended at approximately 35-40 years of age, since it has proven survival benefit and reductions in the risk of ovarian cancer in these women [26]. 
Table 2 Summary of secondary prevention recommendations

\begin{tabular}{|c|c|c|}
\hline Type of Tumor & Recommendation & $\begin{array}{l}\text { Level of Rec- } \\
\text { ommendation } \\
\text { (GRADE) }\end{array}$ \\
\hline \multirow[t]{5}{*}{ Breast cancer } & For women at intermediate risk, $50-69$ years of age: Mammogram every 2 years & $\begin{array}{l}\text { Grade 1B } \\
\text { Grade 2C }\end{array}$ \\
\hline & $\begin{array}{l}\text { For women at intermediate risk, } 45-49 \text { years and } 70-74 \text { years of age: Mammogram every } \\
2 \text { years }\end{array}$ & Grade $2 \mathrm{C}$ \\
\hline & $\begin{array}{l}\text { For women at high risk (e.g., carriers of pathogenic mutations of BRCA or other suscepti- } \\
\text { bility genes, prior chest radiotherapy, positive family history): yearly magnetic resonance }\end{array}$ & Grade $2 \mathrm{~A}$ \\
\hline & Breast self-examination: not recommended & Grade 2B \\
\hline & Clinical breast examination: not recommended & Grade 2C \\
\hline \multirow[t]{8}{*}{ Colorectal cancer } & Individuals at intermediate risk, $50-69$ years of age: & \\
\hline & Immunohistochemical fecal occult blood test (FOBTi) every 2 years & Grade 1A \\
\hline & Complete colonoscopy every 10 years & Grade 1A \\
\hline & Flexible sigmoidoscopy every 5 years & Grade 1A \\
\hline & Fecal DNA analysis every 3 years & Grade 2B \\
\hline & CT colonography every 5 years & Grade 2B \\
\hline & $\begin{array}{l}\text { Individuals at intermediate risk between } 50 \text { and } 69 \text { years of age: If FOBT positive: com- } \\
\text { plete colonoscopy }\end{array}$ & Grade $1 \mathrm{~A}$ \\
\hline & $\begin{array}{l}\text { Individuals at high risk (e.g., family or personal history of polyps or CRC, Lynch syn- } \\
\text { drome, intestinal inflammatory disease): specific screening measures }\end{array}$ & Grade 1A \\
\hline \multirow[t]{2}{*}{ Prostate cancer } & $\begin{array}{l}\text { Men at high risk, aged } 50-69 \text { years: individual conversation PSA determinations every } \\
1-2 \text { years without digital rectal exam }\end{array}$ & Grade 1C \\
\hline & Men at intermediate risk $\geq 70$ years of age: Screening not recommended & Grade 1D \\
\hline $\begin{array}{l}\text { Lung cancer (U.S. preventive ser- } \\
\text { vices task force recommendation) }\end{array}$ & $\begin{array}{l}\text { Individuals at high risk (who currently smoke or have quit within the past } 15 \text { years; } \\
\text { minimum } 30 \text { packs/year, and 55-74 years of age): Low density computerized tomogra- } \\
\text { phy + advice to quit smoking }\end{array}$ & Grade 1B \\
\hline \multirow[t]{2}{*}{ Ovarian cancer } & Women at intermediate risk $>40$ years of age: screening not recommended & Grade 2D \\
\hline & $\begin{array}{l}\text { Women at risk high (e.g., carriers of pathogenic BRCA gene mutations): Gynecological } \\
\text { and transvaginal ultrasound + CA } 125 \text { Determinations every 6-12 months starting at } \\
35 \text { years of age }\end{array}$ & Grade 2B \\
\hline \multirow[t]{2}{*}{ Gastric cancer } & $\begin{array}{l}\text { Individuals at high risk (e.g., Lynch syndrome, hereditary diffuse gastric cancer): regular } \\
\text { gastroscopy }\end{array}$ & Grade 2B \\
\hline & Individuals at intermediate risk: screening not recommended & Grade 2D \\
\hline
\end{tabular}

\section{Skin cancer}

There are no known data that endorse early diagnosis of skin cancer and melanoma in the general population, although in geographical regions with a high prevalence of skin tumors, such as Scotland and Australia, early detection programs are conducted in the general population by means of dermatological and physical examinations.

\section{Gastric cancer}

Screening is not recommended in the general population (Grade 2D), although in individuals with hereditary syndromes such as Lynch syndrome or hereditary diffuse [gastric] cancer syndrome (CDH1 gene mutations) and with scant scientific evidence, regular gastroscopy is recommended; there are even some reports of prophylactic gastrectomy in patients with mutated CDH1. The risk of developing gastric cancer will be evaluated on a case-by-case basis according to [the person's] background and clinical characteristics and the close monitoring to be carried out (Grade 2B).

\section{Conclusions}

Secondary prevention of the leading tumors has been proven to decrease incidence and mortality to a greater or lesser degree, albeit levels of evidence vary in the different neoplasms. Screening programs must be put into practice and good coverage is fundamental if they are to meet their objectives. Table 2 shows a summary of the recommendations.

\section{Compliance with ethical standards}

Conflict of interest All authors declare that they have no conflict of interest. 
Ethical approval The current study has been performed in accordance with the ethical standards laid down in the 1964 Declaration of Helsinki and its later amendments.

Informed consent None.

Open Access This article is licensed under a Creative Commons Attribution 4.0 International License, which permits use, sharing, adaptation, distribution and reproduction in any medium or format, as long as you give appropriate credit to the original author(s) and the source, provide a link to the Creative Commons licence, and indicate if changes were made. The images or other third party material in this article are included in the article's Creative Commons licence, unless indicated otherwise in a credit line to the material. If material is not included in the article's Creative Commons licence and your intended use is not permitted by statutory regulation or exceeds the permitted use, you will need to obtain permission directly from the copyright holder. To view a copy of this licence, visit http://creativecommons.org/licenses/by/4.0/.

\section{References}

1. Data Source: GLOBOCAN 2018. Cancer incidence and mortality worldwide: IARC CancerBase. Available at Global Cancer Observatory: http://gco.iarc.fr.

2. Data Source: REDECAN—Red Española de Registros de Cancer. http://redecan.org/is.

3. Organización Mundial de la Salud. Promoción de la Salud Glosario. Organ Mund La Salud. 1998;1-35.

4. Manual SEOM de prevención y diagnóstico precoz del cáncer. Coordinación Dr. Juan Bayo Calero. SEOM 2017. ISBN 978-84-697-4630-1.

5. Oeffinger KC, Fontham ET, Etzioni R, Herzig A, Michaelson JS, Shih YC, et al. Breast cancer screening for women at average risk: 2015 guideline update from the American Cancer Society [published correction appears in JAMA. 2016 Apr 5;315(13):1406]. JAMA. 2015;314(15):1599-614.

6. Nelson HD, Fu R, Cantor A, Pappas M, Daeges M, Humphrey L. Effectiveness of breast cancer screening: systematic review and meta-analysis to update the 2009 US preventive services task force recommendation. Ann Intern Med. 2016;164(4):244-55. https:// doi.org/10.7326/m15-0969 (Epub 2016 Jan 12).

7. Passaperuma K, Warner E, Causer PA, et al. Long-term results of screening with magnetic resonance imaging in women with BRCA mutations. Br J Cancer. 2012;107(1):24-30.

8. Thomas DB, Gao DL, Ray RM, Wang WW, Allison CJ, Chen FL, et al. Randomized trial of breast self-examination in Shanghai: final results. J Natl Cancer Inst. 2002;94(19):1445-57.

9. Simms KT, Steinberg J, Caruana M, Smith MA, Lew JB, Soerjomatarn I, et al. Impact of scaled up human papillomavirus vaccination and cervical screening and the potential for global elimination of cervical cancer in 181 countries, 2020-99: a modelling study. Lancet Oncol. 2019;20:394-407.

10. Arbyn M, Anttila A, De Vuyst H, Dillner J, Dillner L, Franceschi $\mathrm{S}$ et al. European guidelines for quality assurance in cervical cancer screening. Second edition-Supplements. European Union, 2015.

11. Las cifras del cancer en España 2019. SEOM, 2019. http://www. seom.org/dmcancer/wp-content/uploads/2019/Informe-SEOMcifras-cancer-2019.pdf. Accessed 16 Aug 2019.

12. Rex DK, Boland CR, Dominitz JA, Giardiello FM, Johnson DA, Kaltenbach T, et al. Colorectal cancer screening: Recommendations for physicians and patients from the Manual SEOM de prevención y diagnóstico precoz del cáncer. Coordinación Dr U.S. Multi-Society Task Force on Colorectal Cancer. Gastroenterology. 2017; 153:307-23.

13. Wolf AMD, Fontham ETH, Church TR, Flowers CR, Guerra CE, LaMonte SJ, et al. Colorectal cancer screening for average-risk adults: 2018 guideline update from the American Cancer Society. CA Cancer J Clin. 2018;68:250-81.

14. Lauby-Secretan B, Vilahur N, Bianchini F, Guha N, Straif K, International Agency for Research on Cancer Handbook Working Group. The IARC perspective on colorectal cancer screening. N Engl J Med. 2018;378:1734-40.

15. Ilic D, Neuberger MM, Djulbegovic M, Dahm P. Screening for prostate cancer. Cochrane Database Syst Rev. 2013;1:CD004720.

16. Wolf AM, Wender RC, Etzioni RB, Thompson IM, D'Amico $\mathrm{AV}$, Volk RJ, et al. American Cancer Society guideline for the early detection of prostate cancer: update 2010. CA Cancer J Clin. 2010;60:70.

17. Grossman DC, Curry SJ, Owens DK, Bibbins-Domingo K, Caughey AB, Davidson KW, et al. Screening for prostate cancer: US preventive services task force recommendation statement. JAMA. 2018;19:1901-13.

18. Ministerio de Sanidad, Servicios Sociales e Igualdad. Muertes atribuibles al consumo de tabaco en España, 2000-2014. Madrid: Ministerio de Sanidad, Servicios Sociales e Igualdad, 2017.

19. The National Lung Screening Trial Research Team. Reduced lung-cancer mortality with low-dose computed tomographic screening. N Engl J Med. 2011;365:395-409.

20. Field JK, Duffy SW, Baldwin DR, Brain KE, Devaraj A, Eisen T, Green BA, Holemans JA, Kavanagh T, Kerr KM, Ledson M, Lifford KJ, McRonald FE, Nair A, Page RD, Parmar MK, Rintoul RC, Screaton N, Wald NJ, Weller D, Whynes DK, Williamson PR, Yadegarfar G, Hansell DM. The UK Lung Cancer Screening Trial: a pilot randomised controlled trial of low-dose computed tomography screening for the early detection of lung cancer. Health Technol Assess. 2016;20(40):1-146.

21. Pastorino U, Silva M, Sestini S, Sabia F, Boeri M, Cantarutti A, Sverzellati N, Sozzi G, Corrao G, Marchianò A. Prolonged lung cancer screening reduced 10-year mortality in the MILD trial: new confirmation of lung cancer screening efficacy. Ann Oncol. 2019;30(7):1162-9.

22. Humphrey LL, Deffebach M, Pappas M, Baumann C, Artis K, Mitchell JP, Zakher B, Fu R, Slatore CG. Screening for lung cancer with low-dose computed tomography: a systematic review to update the US Preventive services task force recommendation. Ann Intern Med. 2013;159(6):411-20.

23. Oudkerk M, Devaraj A, Vliegenthart R, Henzler T, Prosch H, Heussel CP, Bastarrika G, Sverzellati N, Mascalchi M, Delorme S, Baldwin DR, Callister ME, Becker N, Heuvelmans MA, Rzyman W, Infante MV, Pastorino U, Pedersen JH, Paci E, Duffy SW, de Koning H, Field JK. European position statement on lung cancer screening. Lancet Oncol. 2017;18(12):e754-66.

24. Van Nagell JR, Miller RW, De Simone CP, et al. Long term survival of women with epithelial ovarian cancer detected by ultrasonographic screening. Obstet Gynecol. 2011;118(6):1212-21.

25. US preventive services task force recommendations. https:// www.uspreventiveservicestaskforce.org/Page/Name/home.

26. Llort G, Chirivella I, Morales R, Serrano R, Sanchez AB, Teulé A, Lastra E, Brunet J, Balmaña J, Graña B. SEOM clinical guidelines in hereditary breast and ovarian cancer. Clin Transl Oncol. 2015;17(12):956-61.

Publisher's Note Springer Nature remains neutral with regard to jurisdictional claims in published maps and institutional affiliations. 